\title{
Is aging a problem?: Dependency, long-term care, and public policies in Chile
}

\author{
Pablo Villalobos Dintrans ${ }^{1}$
}

Suggested citation Villalobos Dintrans P. Is aging a problem?: Dependency, long-term care, and public policies in Chile. Rev Panam Salud Publica. 2018;42:e168. https:/ / doi.org/10.26633/RPSP.2018.168

\begin{abstract}
Chile is facing changes associated with the demographic transition. So far, these challenges have been framed as age related. This has contributed to approaching a broad set of issues from a narrow perspective. The focus on aging has fragmented a multidisciplinary problem into different parts-particularly health and social policies-with different actors dealing with it from the perspective of their own sector. This process has generated an incomplete picture, preventing the definition and measurement of dependency and long-term care, and hindering a coordinated response to these issues. This article advocates for a change in the definition of the problem, by adopting the concept of long-term care, in order to gain a deeper and more comprehensive perspective on the issues arising from the situation that Chile is experiencing.
\end{abstract}

Keywords Aging; long-term care; public policy; dependency (psychology); Chile.

Without a doubt, Chile is aging. Although the country is still young today, it will quickly grow older in the coming decades. Over the next 20 years, it is projected that the elderly (people over 65 years old) will go from roughly $11 \%$ to $20 \%$ of the population. In the same period, the share of the population over 80 will climb from $2.5 \%$ to almost $6.0 \%$ (1).

The rapid demographic change in the country has caught the attention of policymakers and scholars, who have started to push for putting the issue on the agenda, but mostly framing it as an age-related problem (2-4).

This paper calls for a different approach in dealing with the challenges posed by the demographic transition.

Harvard T.H. Chan School of Public Health, Boston, Massachusetts, United States of America. Send correspondence to Pablo Villalobos Dintrans, at pvillalobos.d@gmail.com
As highlighted by Thumala et al. (4), one of the main issues that policymakers need to acknowledge is the high heterogeneity among elders. Even though they all can be classified in the same group by age, their conditions-particularly health status-can be very different. Some elderly are completely dependent, while others enjoy good health. Treating the problem as one of aging fails to capture its true dimension. This article argues that a different approach is needed, highlighting the necessity to start thinking more about long-term care needs and dependency, and less about aging.

\section{FRAMING THE PROBLEM: AGING VERSUS LONG-TERM CARE NEEDS}

Despite the facts available and the consensus about its relevance, the issue of aging and age-related problems has been, until recently, neglected in Chile. In addition, the concept of long-term care is simply absent from any debate.

Long-term care (LTC) consists of the activities undertaken by others to ensure that people with a significant ongoing loss of intrinsic capacity can maintain a level of functional ability consistent with their basic rights, fundamental freedoms, and human dignity (5). LTC has been increasing its importance in the public debate around the world. Some member countries of the Organization for Economic Cooperation and Development (OECD) have started reform processes to implement LTC systems, in order to deal with the increase in LTC needs (6-8).Why has the issue been absent from the public debate in Chile?

According to Kingdon's agenda-setting framework (9), problems, policies, and politics need to be aligned in order to put a new issue on the agenda. Kingdon uses 
the case of long-term care as a classic example of an issue that, while being recognized as important, has been permanently ignored by policymakers. He argues that in the case of LTC, the main barrier has been the lack of feasible solutions to the problem. I would add that, in the case of Chile, the definition of the problem has been and is still unclear.

As stated above, there is awareness of the rapid demographic change in Chile and of various challenges that come with that shift. This article tries to answer: i) why the challenges posed by demographic changes have been framed as age-related problems and ii) what the consequences of this approach are.

There are several reasons why defining the problem from an age perspective is reasonable. First, age is a simple concept and very easy to understand. Just like this document, many articles start by showing that society's age structure is changing and that this change involves adjustments in various aspects of life. On the other hand, defining LTC needs has proven to be an immense challenge. Although most descriptions are related to the idea of functionality, there is no consensus definition for the concept $(2,5,10)$.

Another related reason for the attraction of using the age frame is that the concept is both easier to grasp and easier to measure. Even though LTC definitions have usually been operationalized through the concept of dependency (i.e., the need for help from other persons in living their lives), there are several instruments to measure it. This difficulty in measuring dependency is evident in the case of Chile. When looking at the past 15 years, surveys and studies have struggled with definition and measurement issues. The first studies on the topic were mostly focused on age and disability; both of those concepts are related to but not equal to dependency $(11,12)$. The SABE study (13) and the study on dependency in the elderly population developed by the Chilean National Service for Older Persons (SENAMA) (2) pioneered in using the concept of dependency and in defining a specific methodology to measure it. More recently, the 2015 version of the National Socioeconomic Characterization Survey (CASEN) incorporated a module to measure dependency (3), using the definitions proposed by SENAMA in 2010 (2). Before this dataset was available, there were few estimates of dependency in the country, and all were limited to the elderly population.

Finally, the aging approach not only makes the issues of dependency and long-term care easier to understand (by using a well-known concept) and measure (by using well-defined instruments), but also easier to address. The standard strategy has been to link age to health and to present the problem as one related to the burden of disease. Even though LTC is closely related to age and health status (14-16), these are not the only dimensions of the problem. As recognized by Thumala et al. (4), there is also a social component attached to the concepts of long-term care and dependency. Defining the problem from a holistic perspective entails a multisectoral effort and coordination that is harder to achieve. Alternatively, as many countries have done, addressing the problem as "longterm care" requires the creation of new institutions to deal with the specificities and complexities of LTC. Limiting the problem to a "health issue" or a "social issue" makes it simpler to address by using institutions currently in place, such as the health system or the social protection system.

But all these advantages have downsides. Framing the problem as "aging" is simpler but incomplete. It is necessary to "create" a coherent problem to push for coordinated policies. At the root of the problem, there are people with LTC needs and their caregivers, who require support to live their lives with dignity. The fragmentation of the issue of LTC needs has allowed tackling them from different angles but, at the same time, has made the real problem invisible.

Defining the problem as aging leads to inaction. If the problem is that we are getting old, it does not look like a problem at all. This may seem to be merely a semantic argument, but it has proved to be an important one. In general, Chile has good population and health statistics. However, there is no official information on the number of dependents and their needs. In fact, Chile is one of the few member countries that report no data on LTC to the $\operatorname{OECD}(8,17)$. This means that, in the eyes of the public, the problem does not exist, even though there are dependents and caregivers confronting the issue every day. The lack of information makes it difficult to design public policies to deal with the challenges posed by the increase in longterm care needs in the country (18).

In addition, the fragmentation of the problem prevents a systemic response to this complex issue. When defining LTC needs just in terms of health, there is an unavoidable temptation to make a link with particular health conditions. Vertical programs have a long tradition in health care (19), and Chile is no exception. For example, the Explicit Health Guarantees (GES) reform of 2005 was designed following this logic. The GES establishes a legal obligation for health insurers to offer certain benefits for a well-defined list of medical interventions that are associated with specific health conditions (20). From this perspective, the debate quickly turned into a discussion about what condition we are fighting when we talk about long-term care or dependency. Is it noncommunicable diseases? Mental health? Disability?

Just as the health sector approaches LTC from its point of view, the social sector uses its own definitions and solutions. In Chile, dependency has been (tacitly) addressed by two main institutions: the Ministry of Health $(\mathrm{MoH})$ and the Ministry of Social Development (MSD). The $\mathrm{MoH}$ has implemented prevention and rehabilitation programs, mostly focused on maintaining and improving health conditions. The MSD has also embraced the topic of aging, but instead of focusing on age-related health problems, it has framed the problem as one associated with "vulnerability," particularly in the elderly population. Consequently, the institution has designed programs and policies to help seniors in poverty.

Under this logic, the new problem is transformed into a traditional one (health conditions or poverty), and known solutions are applied (health care or social policies). In the process, relevant pieces are missing. Dependency (not age) combines both dimensions (health and social conditions), and this definition is required to measure the scale of the problem and start designing and implementing integrated solutions.

Finally, the higher prevalence of dependency among the elderly in Chile has usually been used as a rationale to link and limit the problem of LTC to this particular group. As mentioned earlier, most studies measuring dependency in the country show statistics just for the elderly population $(2,3)$. Even though 
this can be a good targeting strategy, using age as the sole criterion to identify LTC needs reduces its real scale. Using information from the CASEN 2015 survey, it is estimated that roughly $40 \%$ of the dependents in Chile are younger than 65 years old. Framing the issue as one exclusively related to age leads to ignoring an important part of the problem.

\section{DISCUSSION}

Chile is starting the debate on how to deal with increasing LTC needs. The definition of the problem will be relevant to deciding how to continue along this path. The MSD is designing and implementing a pilot program for a national system of care. The initiative is relevant, but it highlights the confusion and lack of consensus about what the country is trying to solve and how to do that. The new system is based on an instrument to measure dependency and social vulnerability. The tool is useful for selecting beneficiaries, but not for estimating LTC needs in the country. Additionally, instead of generating new information, it relies on information currently available in its information system, which also gives a partial view of the problem (21).

The lack of an intersectoral view makes it harder to obtain a full understanding and treatment of the problem. As with focusing solely on health conditions, concentrating exclusively on activities of daily living (ADLs) to measure dependency (as the MSD does) limits its scope, ignoring, for example, the mental health (dementia) component. Estimates for the United States of America show that almost $38 \%$ of the elderly with loss of functionality (dependency) could be classified in this group exclusively due to cognitive impairment, and only $27 \%$ would be eligible exclusively based on difficulties in performing ADLs (22). Working on a comprehensive definition and measurement tool will allow Chile to have a better diagnosis of the problem and also avoid the need to reform the LTC system in the future. Such reforms can be long and complex, as shown by the experiences of several countries $(23,24)$. It is essential not to confound LTC needs assessment with practical criteria for assessing the eligibility of the LTC system's beneficiaries.

The LTC issue also has an important gender component that is ignored when using only age, health, or vulnerability as guides. The focus on the patient or beneficiary overlooks the role of caregivers as part of an LTC system. The LTC perspective incorporates the idea of the patientcaregiver dyad, adding a new dimension to the problem. As in most countries around the world, caregivers in Chile have health issues (25-28), have fewer opportunities for paid work $(3,29,30)$, and are mostly women $(6,31)$. This shows the existence of a clear gender bias in the LTC sphere. Ignoring the concept of dependency and the role of caregivers helps perpetuate women's traditional role in society and increases gender-based inequalities $(32,33)$.

In summary, Chile needs to confront the demographic change and its challenges from a holistic perspective, looking for comprehensive solutions to a multidimensional problem that interweaves age, gender, and socioeconomic status.

\section{REFERENCES}

1. Comisión Económica para América Latina. Estimaciones y proyecciones de población total, urbana y rural, y económicamente activa. América Latina - revisión 2017. Santiago: CEPAL; 2017. Available from: https://www.cepal.org/es/temas/proyecciones-demograficas / estimacionesproyecciones-poblacion-total-urbanarural-economicamente-activa Accessed 21 September 2017.

2. Servicio Nacional del Adulto Mayor. Estudio Nacional de la Dependencia en Personas Mayores. Santiago: SENAMA; 2010.

3. Ministerio de Desarrollo Social. CASEN 2015. Adultos mayores: síntesis de resultados. Santiago: MDS; 2017. Available from: http:/ / observatorio.ministeriodesarrollosocial.gob.cl/casen-multidimensional/ casen/docs /CASEN_2015_Resultados_ adultos_mayores.pdf Accessed 22 September 2017.

4. Thumala D, Kennedy BK, Calvo E, Gonzalez-Billault C, Zitko P, Lillo P, et al. Aging and health policies in Chile: new agendas for research. Health Syst Reform. 2017;3(4):253-60.

5. World Health Organization. World Report on Ageing and Health. Geneva: WHO; 2015. 6. Colombo F, Llena-Nozal A, Mercier J, Tjadens F. Help wanted. Providing and paying for long-term care. Paris: OECD Publishing; 2011.

7. Swartz K. Searching for a balance of responsibilities: OECD countries' changing elderly assistance policies. Annu Rev Public Health. 2013;34:397-412.
A narrow definition of dependency and LTC (using age, health, or vulnerability) presents a limited set of solutions, hides the major issue, and slows the creation of new alternatives to address these problems. On the one hand, the "medicalization" of the problem involves solving the issue through the health system; on the other hand, the "socialization" of the problem suggests a solution based on social policies. Both approaches create extra pressures on an already stressed social security system. This has been the main argument used in other countries when highlighting the urgency of designing and implementing LTC systems (35-40).

As with as other countries dealing with similar issues, Chile needs to start building a shared language, in order to agree on the collective problem. That is the first step toward thinking of a coordinated solution to the challenges posed by the increase in long-term care needs in our countries.

Acknowledgments. I would like to thank Mamka Anyona, Christine Bohne, Vanessa Brizuela, and Claire Chaumont for their helpful comments and inspiring discussion. However, I assume responsibility for any mistakes. Corrections and suggestions made by free-lance technical editor Bill Black helped to enormously improve the original version of the article.

\section{Conflicts of interest. None declared.}

Disclaimer. The author holds sole responsibility for the views expressed in the manuscript, which may not necessarily reflect the opinion or policy of the RPSP/PAJPH or PAHO.
8. Villalobos Dintrans P. Envejecimiento y cuidados a largo plazo en Chile: desafíos en el contexto de la OCDE. Rev Panam Salud Publica. 2017;41:e86.

9. Kingdon JW. Agendas, alternatives, and public policies. Boston: Pearson; 1995.

10. Organisation for Economic Co-operation and Development; European Commission. A good life in old age? Monitoring and improving quality in long-term care. Paris: OECD Publishing; 2013.

11. Ministerio de Salud. Encuesta Nacional de Salud ENS Chile 2003. Santiago: MINSAL; 2003. Available from: http://www.medicinadefamiliares.cl/Protocolos/encnacsalres. pdf Accessed 21 September 2017.

12. Fondo Nacional de la Discapacidad. Primer Estudio Nacional de la Discapacidad en 
Chile. Santiago: FONADIS; 2004. Available from: http:/ /www.senadis.gob.cl/pag/ 136/1196/resultados_endisc_i Accessed 23 September 2017.

13. Organización Panamericana de la Salud. Salud, bienestar y envejecimiento en Santiago, Chile. SABE 2000. Washington, D.C.: OPS; 2005. Available from: http:// iris.paho.org/xmlui/bitstream/handle/123456789/741/9275316090.pdf?sequence $=1$ Accessed 23 September 2017.

14. Manton KG, Stallard E. Medical demography: interaction of disability dynamics and mortality. In: Martin LG, Preston SH, eds. Demography of aging. Washington, D.C.: National Academy Press; 1994: 217-78.

15. Freedman VA, Martin LG, Cornman J, Agree EM, Schoeni RF. Trends in assistance with daily activities: racial/ethnic and socioeconomic disparities persist in the U.S. older population. In: Cutler DM, Wise DA, eds. Health at older ages: the causes and consequences of declining disability among the elderly. Chicago: University of Chicago Press; 2008:411-38.

16. Fuentes $P$, Albala C. An update on aging and dementia in Chile. Dement Neuropsychol. 2014;8(4):317-22.

17. Organisation for Economic Co-operation and Development. OECD health statistics 2017. Paris: OECD; 2017. Available from: http:/ /www.oecd.org/els/health-systems/ health-data.htm Accessed 27 September 2017.

18. Scheil-Adlung X. Long-term care protection for older persons: a review of coverage deficits in 46 countries. Geneva: International Labour Office; 2015.

19. Atun RA, Bennett S, Duran A. When do vertical (stand-alone) programmes have a place in health systems? Geneva: World Health Organization; 2008. Available from: http://www.euro.who.int/ data / assets /pdf_file / $0008 / 75491 /$ E93417.pdf?ua=1 Accessed 28 September 2017.

20. Bitrán R. Explicit health guarantees for Chileans: the AUGE benefits package. Washington, D.C.: World Bank; 2013.
21. Ministerio de Desarrollo Social. Subsistema Nacional de Apoyos y Cuidados - documento marco. Santiago: Comité Técnico Interministerial Desarrollo Social; 2017.

22. Stallard E. Long term care for aging populations. In: Heggenhougen HK, Quah S, eds. International encyclopedia of public health. San Diego: Academic Press; 2008:447-58

23. Federal Ministry of Health. Report by the Advisory Board to Review the Definition of the Need for Long-Term Care. Bonn: Federal Ministry of Health; 2009.

24. Jeon B, Kwon S. Health and long-term care systems for older people in the Republic of Korea: policy challenges and lessons. Health Syst Reform. 2017;3(3):214-23.

25. Albala C, Sánchez H, Bustos C, Fuentes A. Informe final: situación de los cuidadores domiciliarios de adultos mayores dependientes con pensión asistencial. Santiago: Servicio Nacional del Adulto Mayor; 2007.

26. Slachevsky A, Budinich M, MirandaCastillo C, Nunez-Huasaf J, Silva JR, Muñoz-Neira $C$, et al. The CUIDEME Study: determinants of burden in Chilean primary caregivers of patients with dementia. J Alzheimers Dis. 2013;35(2): 297-306.

27. Arechalaba M, Catoni M, Palma E, Barrios S. Depresión y autopercepción de la carga del cuidado en pacientes en hemodiálisis y sus cuidadores. Rev Panam Salud Publica. 2011;30(1):74-9.

28. Orta OR, Barbosa, Velez JC, Gelaye B, Chen X, Stoner L, et al. Associations of self-reported and objectively measured sleep disturbances with depression among primary caregivers of children with disabilities. Nat Sci Sleep. 2016;8:181-8.

29. Espinoza K, Jofré V. Sobrecarga, apoyo social y autocuidado en cuidadores informales. Cienc Enferm. 2012;18(2):23-30.

30. Hojman DA, Duarte F, Ruiz-Tagle J, Budinich M, Delgado C, Slachevsky A. The cost of dementia in an unequal country: the case of Chile. PLoS One. 2017;12(3):e0172204.

31. Mayston R, Guerra M, Huang Y, Sosa AL, Uwakwe R, Acosta I, et al. Exploring the economic and social effects of care dependence in later life: protocol for the 10/66 research group INDEP study. Springerplus. 2014;3(1):379.

32. Vaquiero S, Stiepovich J. Cuidado informal: un reto asumido por la mujer. Cienc Enferm. 2010;16(2):9-16.

33. Hardy C. El reto de un sistema de cuidados en el contexto de la protección social. In: Forttes P, ed. Dependencia y apoyo a los cuidados, un asunto de derechos humanos. Santiago: Palacio de la Moneda; 2017:19-33.

34. Brodsky J, Clarfield A. Long term care in health services. In: Heggenhougen HK, Quah S, eds. International encyclopedia of public health. San Diego: Academic Press; 2008:459-63.

35. Schenieder U. Germany's social long-term care insurance: design, implementation and evaluation. Int Soc Secur Rev. 1999;52:31-74.

36. Campbell JC, Ikegami N, Kwon S. Policy learning and cross-national diffusion in social long-term care insurance: Germany, Japan, and the Republic of Korea. Int Soc Secur Rev. 2009;62(4):63-80.

37. Campbell JC, Ikegami N. Long-term care insurance comes to Japan. Health Aff. 2000;19(3):26-39.

38. Rhee JC, Done N, Anderson GF. Considering long-term care insurance for middle-income countries: comparing South Korea with Japan and Germany. Health Policy. 2015;119(10):1319-29.

39. Choi YJ. Long-term care of older persons in the Republic of Korea. Bangkok: United Nations Economics and Social Commission for Asia and the Pacific; 2015.

40. Norton EC. Health and long-term care. In Piggott, Woodland A, eds. Handbook of the economics of population aging, Volume 1B. Amsterdam: North-Holland; 2016:951-89.

Manuscript received on 17 October 2017. Revised version accepted for publication on 18 June 2018.
RESUMEN

\section{¿Es el envejecimiento un problema? Dependencia, atención a largo plazo y políticas públicas en Chile}

Palabras clave
Chile está enfrentándose a cambios asociados con la transición demográfica. Hasta ahora, estos retos se han considerado como relacionados exclusivamente con la edad. Esto ha hecho que un conjunto amplio de problemas se aborde desde una perspectiva limitada. Al poner el énfasis en el envejecimiento, se ha dividido un problema multidisciplinario en diferentes partes —en particular, en políticas sociales y de saludcon diferentes actores que tratan el tema desde la perspectiva de su propio sector. Este proceso ha generado una imagen incompleta que no ha permitido definir ni medir la dependencia y la atención a largo plazo, y que ha impedido desarrollar una respuesta coordinada frente a estos temas. En este artículo se aboga por cambiar la definición del problema, adoptando el concepto de la atención a largo plazo, a fin de lograr una perspectiva más profunda e integral de los problemas que surgen de la situación por la que está pasando Chile.

Envejecimiento; cuidados a largo plazo; política pública; dependencia (psicología); Chile. 
RESUMO O Chile passa por mudanças associadas à transição demográfica. Até o momento, porém, estes desafios têm sido contextualizados como relacionados com a idade. Isso

O envelhecimento é um problema?: dependência, assistência a longo prazo e políticas públicas no Chile

Palavras-chave vem contribuindo para que uma grande variedade de questões seja contemplada de uma perspectiva restrita. $\mathrm{O}$ foco no envelhecimento reduziu um problema multidisciplinar a vários fragmentos (em particular, políticas sociais e de saúde) com atores de diversos setores lidando com a questão de um prisma distinto. Este processo criou um quadro incompleto que impossibilita definir e mensurar dependência e assistência a longo prazo e impede lidar com estas questões de maneira coordenada. Neste artigo, os autores defendem mudar a definição do problema e adotar o conceito de assistência a longo prazo para conferir uma perspectiva mais aprofundada e abrangente às questões decorrentes da situação pela qual o Chile atravessa.

Envelhecimento; assistência de longa duração; política pública; dependência (psicologia); Chile. 